\title{
Lysozyme activity in ultrastructurally defined fractions of alveolar macrophages after inhalation exposure to nickel
}

\author{
ANNE JOHANSSON, ${ }^{1-3}$ MARGOT LUNDBORG, ${ }^{12} \mathrm{~S} \mathrm{SKOG}^{4}$ CONNIE JARSTRAND, ${ }^{5}$ \\ P CAMNER ${ }^{12}$
}

From the Section of Inhalation Toxicology, ${ }^{1}$ Department of Toxicology, National Institute of Environmental Medicine, S-104 01 Stockholm, Department of Environmental Hygiene, ${ }^{2}$ Karolinska Institute, S-104 01 Stockholm, Wenner-Gren Institute, ${ }^{3}$ Biologi Building, University of Stockholm, S-10691 Stockholm, Department of Medical Radiobiology, ${ }^{4}$ Karolinska Institute, S-104 01 Stockholm, and Department of Clinical Bacteriology, ${ }^{5}$ Roslagstulls Hospital, S-114 89 Stockholm, Sweden

ABSTRACT Rabbits were exposed to $0.6 \mathrm{mg} / \mathrm{m}^{3}$ of nickel as $\mathrm{NiCl}_{2}$ for about one month. After exposure, alveolar macrophages were lavaged from the lung and divided into three fractions by elutriation. Laminated structures in the macrophages were related to fraction number so that the fractions with the largest cells contained the highest number of structures. The lysozyme activity decreased in unfractionated as well as in fractionated macrophages from nickel exposed rabbits. The decrease was most pronounced in the fraction with the smallest macrophages and smallest number of laminated structures. Therefore the pronounced decrease in lysozyme activity seen in this and earlier studies is not caused by the increased amount of surfactant material. Increased amount of surfactant is a hallmark of nickel inhalation exposure and the surfactant material is responsible for the morphological and metabolic effects of the macrophages. The decreased lysozyme activity is probably a direct effect of nickel on the macrophages.

Inhalation exposure of rabbits to low levels $\left(0 \cdot 1-1 \mathrm{mg} / \mathrm{m}^{3}\right)$ of nickel in metallic or soluble form from one to eight months affects alveolar epithelial type II cells; increases the content of phospholipids in the lung, especially disaturated phosphatidylcholines; and alters the morphology and oxidative metabolic activity of alveolar macrophages. ${ }^{1}$ These effects are produced by nickel concentrations similar to, and sometimes even below, the present occupational threshold limit values (TLVs). In the United States the TLV for metallic nickel is $1 \mathrm{mg} / \mathrm{m}^{3}$ and for soluble nickel $0.1 \mathrm{mg} / \mathrm{m}^{3}$. The pattern of effects is similar to that seen in rats after exposure to high concentrations of quartz dust and also similar to the pathological picture seen in the human disease, pulmonary alveolar proteinosis. ${ }^{2-4}$ Neither metallic iron, cobalt or chromium dust, nor chlorides of copper, cobalt, or manganese produce the same effect pattern. ${ }^{15} \mathrm{Cad}$ mium chloride, however, does produce a similar effect of alveolar type II cells and lung content of lipids as nickel chloride; in addition, $\mathrm{Cd}^{2+}$ causes interstitial inflammation. ${ }^{6}$

Exposure of rabbits to low levels $\left(0 \cdot 1 \mathrm{mg} / \mathrm{m}^{3}\right)$ of

Accepted 2 April 1986 metallic nickel or nickel chloride aerosols greatly decreases the lysozyme activity in lung lavage fluid and in macrophages ${ }^{78}$ whereas lysozyme activity increases or is unchanged after exposure to chlorides of cadmium, copper, or cobalt. Lysozyme is bacteriolytic to most Gram positive bacteria and acts synergistically with other immunological mechanisms with other bacteria. ${ }^{9-12}$

Exposure to nickel produces a specific effect pattern. This effect pattern is restricted to changes in alveolar epithelial type II cells and alveolar macrophages and an increase in surfactant material. In vitro experiments indicate that several of the effects on the macrophages are caused by the increased amount of surfactant ${ }^{13}$-for example, certain morphological changes and an increase in metabolic activity, as determined by measuring the macrophages ability to reduce nitroblue tetrazolium (NBT) to formazan. The aim of the present study was to investigate the lysozyme activity in macrophage fractions containing different amounts of laminated inclusions to see whether or not changes in lysozyme activity were related to the increase in surfactant material in the cells. Exposure to nickel produces large variations in the cell size of alveolar macrophages and there is an 
increase in laminated structures, especially in the larger macrophages. ${ }^{1415}$ The nitroblue tetrazolium activity was also studied in the macrophage fractions as a positive control.

\section{Material and methods}

\section{EXPOSURE DATA}

Sixteen male rabbits, weighing $2.6 \pm 0.3 \mathrm{~kg}$, were divided into two groups of eight animals each. One group was exposed to $0.6 \pm 0.2 \mathrm{mg} / \mathrm{m}^{3}$ of $\mathrm{Ni}^{2+}$ as $\mathrm{NiCl}_{2}$ and the other group constituted a control group and was exposed to filtered air only. During the exposure period, which was four to six weeks, five days a week, six hours a day, exposed animals and controls were kept in exposure chambers, $0.6 \mathrm{~m}^{3}$ in size. ${ }^{16}$ The concentration of nickel was measured by air suction through a membrane filter (Gelman Gn-4, $0.8 \mu \mathrm{m})$ and the amount of nickel deposited on the filter was measured using atomic absorption spectrophotometry (Varian AA6). The nickel aerosol was produced with an ultrasonic nebuliser (DeVilbiss 35B). The mass median aerodynamic diameter, estimated by an impactor, was about $1 \mu \mathrm{m} .{ }^{15} 17$

\section{LUNG LAVAGE}

Within three days after the last day of exposure the rabbits were killed by means of an overdose of sodium pentobarbital and the lungs were excised. Both lungs were lavaged with Hank's solution at about $37^{\circ} \mathrm{C}^{18}$ About $80 \mathrm{ml}$ of the lavage fluid were collected.

\section{CELL SEPARATION}

The separation procedure has been described previously. ${ }^{19}$ Briefly, $25-135 \times 10^{6}$ cells in $10 \mathrm{ml}$ Hank's separation buffer were added to the elutriator system (Beckman JE-G elutriator rotor with a Beckman J21 B centrifuge) with an initial buffer flow rate of $32 \mathrm{ml} / \mathrm{min}$. Material collected at this flow rate was referred to as fraction 1. Fractions 2 and 3 were collected at flow rates of 42 and $56 \mathrm{ml} / \mathrm{min}$, respectively. The fraction volume was $100 \mathrm{ml}$. The rotor speed was at $2780 \pm 10 \mathrm{rpm}$ and the temperature $4^{\circ} \mathrm{C}$. After $\frac{2}{\mathbb{D}}$ stopping the rotor, fraction 4 was obtained by wash-? ing the separation chamber with $100 \mathrm{ml}$ separation $\vec{F}$ buffer at a flow rate of $80 \mathrm{ml} / \mathrm{min}$.

\section{MORPHOLOGICAL MEASUREMENTS}

The macrophages were fixed in $2.5 \%$ glutaraldehyde $\frac{\text { क }}{\vec{\nabla}}$ in $0.1 \mathrm{M}$ cacodylate buffer, $\mathrm{pH} 7 \cdot 2$, postfixed in $1 \% \propto$

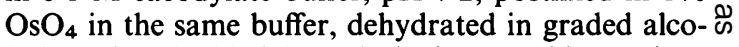
hol, and embedded in Polarbed 812. Thin sections $\vec{\circ}$ were examined in a Jeol 100S electron microscope.

\section{LYSOZYME MEASUREMENTS}

Lysozyme activity was studied using a modification described by Lundblad et $\mathbf{l}^{20}$ of the agar heat killed Micrococcus lysodeikticus lysoplate technique. ${ }^{21}$ The plates contained nine circular wells, $4 \mathrm{~mm}$ in $\vec{A}$ diameter. A $10 \mu \mathrm{l}$ sample was placed in each well. On each plate samples were placed in triplicate together 은 with one standard sample of human lysozyme (the National Swedish Bacteriological Laboratory). In addition, lysozyme standards of $0.25,0.5,1 \cdot 0,2 \cdot 5$, $5 \cdot 0,10 \cdot 0$, and $20.0 \mu \mathrm{g} / \mathrm{ml}$ were tested on separate plates. After 24 hours at $37^{\circ} \mathrm{C}$ the diameter of the clearance zone was measured.

\section{OXIDATIVE METABOLIC ACTIVITY}

The oxidative metabolic activity of the macrophages was determined by measuring their ability to reduce nitroblue tetrazolium to formazan both at rest and in the presence of Escherichia coli bacteria. ${ }^{15}$

\section{STATISTICAL ANALYSIS}

Lysozyme activity data were evaluated using Wilcoxon's U test or Wilcoxon's matched pairs signed ranks test and NBT test data were evaluated using a $t$ test. Direction was not predicted in any of the tests.

\section{Results}

GROSS FINDINGS

The lungs from the exposed rabbits and controls appeared to be essentially normal. Lung lavage fluid

Table 1 Percentage macrophages with 0-3, 4-10, and $>10$ laminated inclusions from rabbits exposed to $0.6 \mathrm{mg} / \mathrm{m}^{3} \mathrm{Ni}^{2+}$ as $\mathrm{NiCl}_{2}$ for four to six weeks, five days a week, six hours a day and from controls. From the exposed rabbits unfractionated macrophages and fractionated macrophages were studied. (Data are given as mean $\pm S D$ )

\begin{tabular}{|c|c|c|c|c|c|}
\hline \multirow[b]{2}{*}{$\begin{array}{l}\text { No of laminated } \\
\text { inclusions/macrophage }\end{array}$} & \multirow[b]{2}{*}{$\begin{array}{l}\text { Controls } \\
(n=7)\end{array}$} & \multicolumn{4}{|c|}{ Exposed macrophages } \\
\hline & & $\begin{array}{l}\text { Unfractionated } \\
\text { macrophages }(\%) \\
(n=8)\end{array}$ & $\begin{array}{l}\text { Macrophages from } \\
\text { fraction } 2(\%) \\
(n=5)\end{array}$ & $\begin{array}{l}\text { Macrophages from } \\
\text { fraction } 3(\%) \\
(n=5)\end{array}$ & $\begin{array}{l}\text { Macrophages from } \\
\text { fraction } 4(\%) \\
(n=7)\end{array}$ \\
\hline $\begin{array}{l}0-3 \\
4-10 \\
>10\end{array}$ & $\begin{array}{r}96 \pm 2 \\
3 \pm 2 \\
1 \pm 1\end{array}$ & $\begin{array}{l}59 \pm 17 \\
27 \pm 8 \\
14 \pm 11\end{array}$ & $\begin{array}{r}89 \pm 5 \\
12 \pm 4 \\
2 \pm 1\end{array}$ & $\begin{aligned} & 78 \pm 10 \\
& 16 \pm 6 \\
& 7 \pm 4\end{aligned}$ & $\begin{array}{l}67 \pm 17 \\
26 \pm 1 \\
11 \pm 8\end{array}$ \\
\hline
\end{tabular}




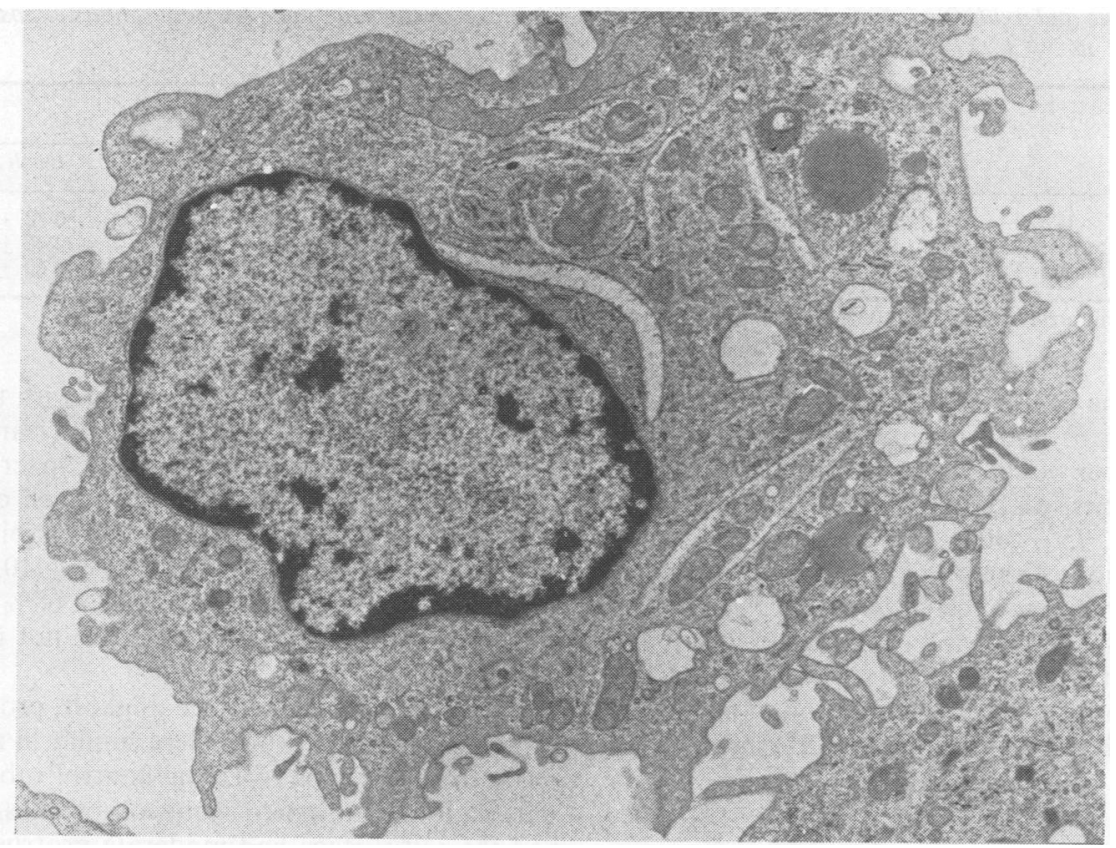

Fig 1 Alveolar macrophage from fraction 2. No laminated inclusions are found in cytoplasm, $\times 8000$.

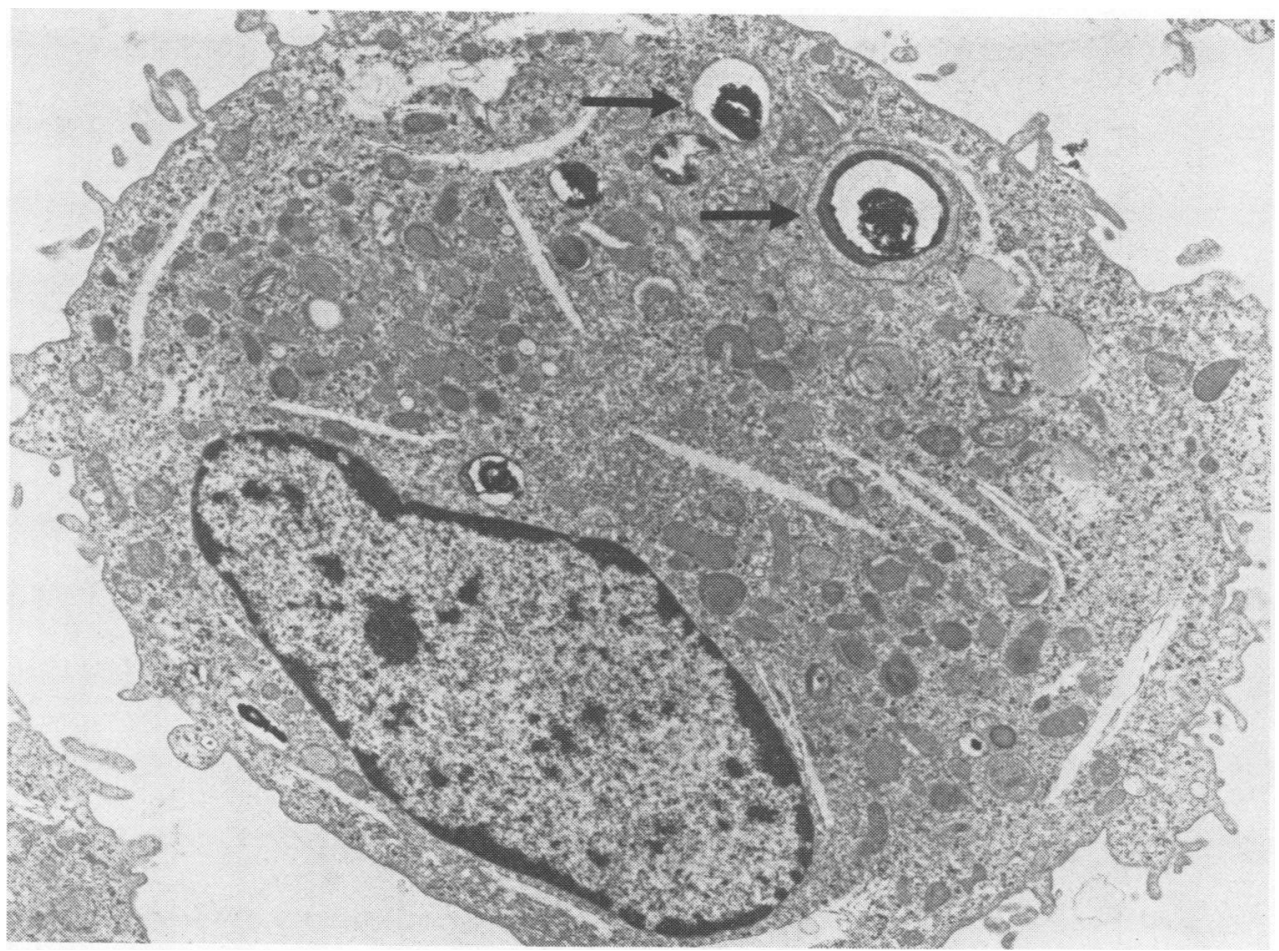

Fig 2 Alveolar macrophage from fraction 3. In this cell four profiles of laminated inclusions are seen (arrow), $\times 7000$. 
Table 2 Lysozyme and oxidative metabolic (NBT test) activities in fractionated macrophages from rabbits exposed to $0.6 \mathrm{mg} / \mathrm{m}^{3}$ of $\mathrm{Ni}^{2+}$ as $\mathrm{NiCl}_{2}$. (Data are given as mean $\pm S D$ ).

\begin{tabular}{|c|c|c|c|}
\hline & \multirow{2}{*}{$\frac{\text { Lysozyme activity }}{\mu \mathrm{g} / 10^{6} \text { macrophages }}$} & \multicolumn{2}{|c|}{ Nitroblue tetrazolium reduction* } \\
\hline & & At rest & E coli stimulation \\
\hline $\begin{array}{l}\text { Macrophages from fraction } 2 \\
\text { Macrophages from fraction } 3 \\
\text { Macrophages from fraction } 4\end{array}$ & $\begin{array}{l}0.9 \pm 0.4(n=6) \\
1.0 \pm 0.5(n=6) \\
1.7 \pm 1.0(n=6)\end{array}$ & $\begin{array}{l}0.13 \pm 0.04(n=6) \\
0.20 \pm 0.09(n=8) \\
0.27 \pm 0.11(n=8)\end{array}$ & $\begin{array}{l}0.32 \pm 0.12(n= \\
0.45 \pm 0.19(n= \\
0.60 \pm 0.21(n=\end{array}$ \\
\hline
\end{tabular}

*Amount of formazan produced by $3 \times 10^{6}$ macrophages during 30 minutes, expressed as optical density.

from many of the rabbits exposed to nickel and from one of the controls had a turbid or opaque appearance. The number of cells lavaged from the lungs of the control rabbits was $37 \pm 15 \times 10^{6}$ and from the exposed rabbits, $95 \pm 40 \times 10^{6}$ (mean $\pm \mathrm{SD}$ ).

After elutriation of the cells from the exposed rabbits the largest number of cells were found in fraction 4 , fewer cells in fraction 3 , and fewer still in fraction 2 . Fraction 1 contained surfactant structures and cell debris. As the number of cells in fractions 2 and 3 was often limited, all tests could not be performed for all rabbits.

\section{MOR PHOLOGY}

Table 1 shows the distribution of laminated inclusions in the macrophages from the exposed rabbits and the controls. The control rabbit with turbid lungo lavage fluid had mácrophages that clearly differedo from the other controls and from the macrophages of 3 the exposed rabbits. Dead cells and cell debris were present in the lavage fluid from this rabbit. The percentages of macrophages with $0-3,4-10$, and $>10+$ laminated inclusions/cell profile were $68 \%, 18 \%$, and $14 \%$ for this rabbit. These data are not included in table 1.

Fraction 2 contained the highest proportion of small macrophages which were similar in appearance to the macrophages from the control rabbits. These cells had $0-3$ laminated inclusion profiles/cell profile $\overrightarrow{0}$ and the cell surface had moderate protrusions (fig 1$)^{\infty}$ (table 1). In fraction 3 there was a small increase in the proportion of macrophages with a moderate num-o

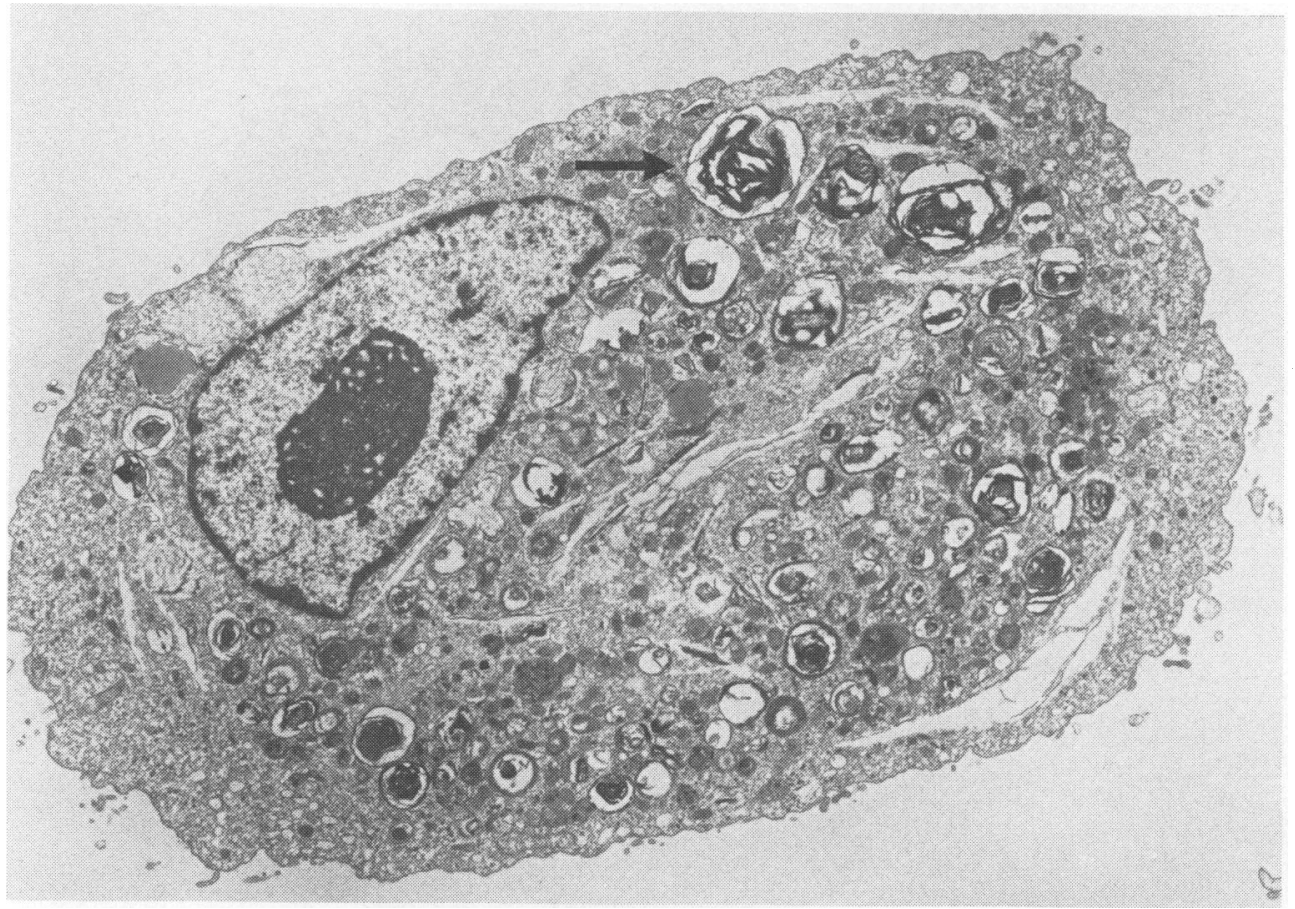

Fig 3 Alveolar macrophage from fraction 4. Many lamellated inclusions (arrow) are present in cytoplasm and surface lacks protrusions, $\times 5000$. 
ber of laminated inclusions, 4-10 profiles/cell profile (fig 2), and in the proportion of macrophages with many inclusions, 10 profiles/cell profile (fig 3 ) (table 1). Fraction 4 contained the highest percentage of macrophages with laminated inclusions. Cells containing a moderate and high number of laminated inclusions were most frequent in this fraction. Cells with closely packed laminated inclusions and lipid droplets were rounded with a smooth surface (fig 3 ) (table 1).

\section{LYSOZYME AND NBT ACTIVITIES}

Lysozyme activity in the lung lavage fluid and in the macrophages was $5.5 \pm 2.3$ (mean \pm SD) and $6.4 \pm$ 2.5 for the controls $(n=7)$, respectively, and $1.4 \pm$ 0.8 and $1.2 \pm 0.7$ for the exposed rabbits $(n=8)$, respectively. Both activities were significantly lower in the nickel exposed animals than in the controls $(p<$ 0.01 ) (table 2). If the control with the morphologically changed macrophages is included the result is similar and the level of significance unchanged. For the fractionated macrophages from the exposed rabbits the lowest activity was found in fraction 2 and the highest in fraction 4. The activity in these two fractions differed significantly $(p<0.05)$ (table 2$)$.

In fractionated macrophages from the exposed rabbits the mean value of the NBT activity, both at rest and during $E$ coli stimulation, increased gradually with the fraction number - that is, with the amount of intracellular surfactant (table 2). The activity in the macrophages from fraction 4 was significantly higher than that in the macrophages from fraction 2 both at rest and during $E$ coli stimulation ( $p<0.02$ and $\mathrm{p}<0.05$, respectively).

\section{Discussion}

The results show that the elutriation procedure is suitable for separating alveolar macrophages from nickel exposed rabbits with respect to size and content of surfactant inclusions. Macrophages from control rabbits are fewer in number, contain few surfactant inclusions, and are more equal in size. ${ }^{14} 15$ In a pilot study where control macrophages were separated by elutriation most cells appeared in fractions 2 and 3 (unpublished data). Because of the small number of cells in the other fractions an investigation, comparable with that performed on macrophages from nickel exposed rabbits, was not feasible. Earlier studies have shown that inhalation exposure to nickel increases NBT activity in macrophages ${ }^{1522}$ and that surfactant material from nickel exposed rabbits increases the NBT activity in vitro. ${ }^{13}$ In this study the NBT values correlated positively with the number of laminated structures in the fractionated cells from the nickel exposed rabbits. This finding supports the assump- tion that the different amounts of laminated structures in the macrophages in the four fractions may be used to study causal relations between increases in surfactant material, induced by nickel exposure, and effects on alveolar macrophages in vivo.

The lysozyme activity in lavage fluid and macrophages was greatly decreased in the nickel exposed rabbits compared with the controls; this agrees with earlier results. ${ }^{78}$ The decrease in lysozyme activity in the fractionated cells was greatest in fraction 2 , whereas fraction 4 , which contained the highest percentage of cells with many laminated inclusions, showed the lowest decrease in lysozyme activity. This indicates that the impairment of lysozyme activity is not related to increased amounts of surfactant material. Thus nickel probably exerts a direct effect on the alveolar macrophages resulting in an impaired lysozyme activity in the lungs.

We are grateful for skilful technical help from Ms Kristina Nyberg. This study was supported by grants from the Swedish Work Environment Foundation and from the Swedish National Association against Heart and Chest Diseases.

\section{References}

1 Camner P. Toxicology of nickel. In: Sunderman FW, Aitio A, Berlin A, Bishop C, eds. Nickel in the human environment. Lyon: International Agency for Research on Cancer, 1984. (IARC sci publ No 53.)

2 Rosen SH, Castleman B, Liebow AA. Pulmonary alveolar proteinosis. $N$ Engl J Med 1958;258:1123-42.

3 Corrin B, King E. Pathogenesis of experimental pulmonary alveolar proteinosis. Thorax 1970;25:230-6.

4 Heppleston AB, Wright NA, Stewart JA. Experimental alveolar lipoproteinosis following the inhalation of silica. J Pathol 1970;101:293-307.

5 Camner P, Curstedt T, Jarstrand C, Johansson A, Robertson B, Wiernik A. Rabbit lung after inhalation of manganese chloride: a comparison with the effects of chlorides of nickel, cadmium, cobalt and copper. Environ Res 1985;38:301-9.

6 Johansson A, Curstedt T, Robertson B, Camner P. Lung morphology and phospholipids after experimental inhalation of soluble cadmium, copper and cobalt. Environ Res 1984;34:295-309.

7 Lundborg M, Camner P. Decreased level of lysozyme in rabbit lung lavage fluid after inhalation of low nickel concentrations. Toxicology 1982;22:353-8.

8 Lundborg M, Camner P. Lysozyme levels in rabbit lung after inhalation of nickel-, cadmium-, cobalt- and copper chlorides. Environ Res 1984;34:335-42.

9 Fleming A. On a remarkable bacteriolytic element found in tissues and secretions. Proc R Soc London, Ser B 93, 1922;306-17.

10 Donaldson MM, Roberts RR, Larsen HS, Tew JG. Inter-relationship between serum beta-lysin, lysozyme, and the antibody-complement system in killing Escherichia coli. Infect Immunol 1974;10:657-66. 
11 Klockars M, Roberts P. Stimulation of phagocytosis by human lysozyme. Acta Haematol 1976;55:289-95.

12 Biggar WD, Sturgess MM. Role of lysozyme in the microbicidal activity of rat alveolar macrophages. Infect Immunol 1977;16:974-82.

13 Wiernik A, Jarstrand C, Johansson A. The effect of phospholipid containing surfactant from nickel exposed rabbits on pulmonary macrophages in vitro. Toxicology 1981;21:169-78.

14 Camner P, Johansson A, Lundborg M. Alveolar macrophages in rabbits exposed to metallic nickel dust. Ultrastructural changes and effect on phagocytosis. Environ Res 1978;16:226-35.

15 Wiernik A, Johansson A, Jarstrand C, Camner P. Rabbit lung after inhalation of soluble nickel. I. Effects on alveolar macrophages. Environ Res 1983;30:129-41.

16 Holma B. Lung clearance of mono- and di-disperse aerosols determined by profile scanning and whole-body
Johansson, Lundborg, Skog, Jarstrand, Camner counting. Acta Med Scand 1967;suppl 473.

17 Mitchell RI, Pilcher KM. Improved cascade impactor $\stackrel{0}{?}$ for measuring aerosol particle sizes. Industrial and Engineering Chemistry 1959;51:1039-42.

18 Lundborg M, Holma B. In vitro phagocytosis of fungal spores by rabbit lung macrophages. Sabouraudia 1972 ; 10:152-6.

19 Skog S, Tribukait B, Sundius G. Energy metabolism and ATP turnover time during the cell cycle of Ehrlich ascites tumour cells. Exp Cell Res 1982;141:23-9.

20 Lundblad G, Hederstedt B, Lind J, Steby M. Chitinase in gout serum. Eur J Biochem 1974;46:367-76.

21 Osserman EF, Lawlor DP. Serum and urinary lysozyme (muramidase) in monocytic and monomyelocytic leukemia. J Exp Med 1966; 124:921-52.

22 Jarstrand C, Lundborg M, Wiernik A, Camner P. Alveolar macrophage function in nickel dust exposed rabbits. Toxicology 1978;11:353-9.

\section{Correspondence and editorials}

The British Journal of Industrial Medicine welcomes correspondence relating to any of the material appearing in the journal. Results from preliminary or small scale studies may also be published in the correspondence column if this seems appropriate. Letters should be not more than 500 words in length and contain a minimum of references. Tables and figures should be kept to an absolute minimum. Letters are accepted on the understanding that they may be subject to editorial revision and shortening.

The journal now also publishes editorials which are normally specially commissioned. The Editor welcomes suggestions regarding suitable topics; those wishing to submit an editorial, however, should do so only after discussion with the Editor. 